\title{
Review \\ Orchestration of Immune Cells Contributes to Fibrosis in IgG4-Related Disease
}

\author{
Naoki Kaneko ${ }^{1, *}$, Masafumi Moriyama ${ }^{1,2}{ }^{10}$, Takashi Maehara ${ }^{1}$, Hu Chen ${ }^{1}$, Yuka Miyahara ${ }^{1}$ \\ and Seiji Nakamura ${ }^{1}$ \\ 1 Section of Oral and Maxillofacial Oncology, Division of Maxillofacial Diagnostic and Surgical Sciences, \\ Faculty of Dental Science, Kyushu University, Fukuoka 812-8582, Japan; \\ moriyama@dent.kyushu-u.ac.jp (M.M.); maeharatakashi1105@gmail.com (T.M.); \\ chenhu961kk@gmail.com (H.C.); yuka.m0119@dent.kyushu-u.ac.jp (Y.M.); seiji@dent.kyushu-u.ac.jp (S.N.) \\ 2 OBT Research Center, Faculty of Dental Science, Kyushu University, Fukuoka 812-8582, Japan \\ * Correspondence: kaneko@dent.kyushu-u.ac.jp
}

Citation: Kaneko, N.; Moriyama, M.; Maehara, T.; Chen, H.; Miyahara, Y.; Nakamura, S. Orchestration of Immune Cells Contributes to Fibrosis in IgG4-Related Disease. Immuno 2022, 2, 170-184. https://doi.org/ 10.3390/immuno2010013

Academic Editor: María Teresa Fiorillo

Received: 14 December 2021

Accepted: 3 February 2022

Published: 10 February 2022

Publisher's Note: MDPI stays neutral with regard to jurisdictional claims in published maps and institutional affiliations.

Copyright: (c) 2022 by the authors. Licensee MDPI, Basel, Switzerland. This article is an open access article distributed under the terms and conditions of the Creative Commons Attribution (CC BY) license (https:/ / creativecommons.org/licenses/by/ $4.0 /)$.

\begin{abstract}
This review summarizes recent progress in understanding the pathogenesis of IgG4-related disease (IgG4-RD), with a focus on fibrosis. Several studies reported that $\mathrm{CD} 4^{+} \mathrm{T}$ cells with cytotoxic activity promoted by the secretion of granzyme and perforin, cytotoxic CD4 ${ }^{+} \mathrm{T}$ cells (CD $\left.4^{+} \mathrm{CTLs}\right)$, and disease-specific activated B cells, infiltrated inflamed tissues and cooperated to induce tissue fibrosis in autoimmune fibrotic diseases such as IgG4-RD, systemic sclerosis, and fibrosing mediastinitis. An accumulation of cells undergoing apoptotic cell death induced by $\mathrm{CD} 4{ }^{+} \mathrm{CTLs}$ and CD8 ${ }^{+}$CTLs followed by macrophage-mediated clearing and finally tissue remodeling driven by cytokines released by CD4 ${ }^{+}$CTLs, activated B cells, and M2 macrophages may contribute to the activation of fibroblasts and collagen production. In IgG4-RD, this process likely involves the apoptosis of non-immune, non-endothelial cells of mesenchymal origin and subsequent tissue remodeling. In summary, $\mathrm{CD} 4{ }^{+} \mathrm{CTL}$ infiltrate affected tissues where they may cooperate with activated B cells, $\mathrm{CD} 8{ }^{+} \mathrm{CTLs}$, and M2 macrophages, to induce apoptosis by secreting cytotoxic cytokines. These immune cells also drive fibrosis by secreting pro-fibrotic molecules in IgG4-RD.
\end{abstract}

Keywords: cytotoxic $\mathrm{CD}^{+}$T cells; activated B cells; macrophages; fibrosis; IgG4-related disease

\section{Introduction and Clinical Features}

Autoimmune fibrotic diseases including systemic sclerosis (SSc), lupus nephritis, fibrosing mediastinitis, and IgG4-related disease (IgG4-RD) are being studied by many rheumatologists and immunologists because of their variety of symptoms and difficulty in treatment, especially in relapse cases. IgG4-RD is still a poorly understood fibrotic disease because details of the immune responses, autoantigens, and roles of autoantibodies and IgG4 have not yet been established. However, the availability of accessible tissue and blood samples, and the ability to compare samples before and after treatment, both provide an opportunity to investigate the underlying mechanisms of the pathogenesis of IgG4-RD and related autoimmune fibrotic diseases, with the hope that this will ultimately lead to a better understanding of the basic immunology related to human immune disease mechanisms. Rather than be part of a unified systemic disease condition, the pathogenesis of IgG4-RD was thought to be an isolated organ-specific condition, a group which includes autoimmune pancreatitis (AIP), Mikulicz's disease, Ormond's disease and idiopathic pseudotumor [1-4]. At the beginning of this century, findings related to its shared disease features, common history, and response to immunosuppression therapy, led to the disease concept of IgG4-RD. A number of reviews have described the clinical features of IgG4-RD, a multi-organ inflammatory condition characterized by elevated serum IgG4 levels and lymphoplasmacytic infiltrate composed of a large population of $\mathrm{IgG}^{+}$plasma cells, storiform fibrosis, and obliterative phlebitis [5-8]. This disease often presents with multiple enlarged organs that 
mimic many malignant, infectious, and inflammatory disorders. The most frequently affected organs are the lacrimal glands, salivary glands, pancreas, kidney, lung, lymph nodes, bile duct, liver, aorta, prostate, and retroperitoneum. Microscopic examination suggests that the enlargement of these affected organs is related to infiltration by activated lymphocytes and storiform fibrosis (Figure 1). The characteristic histopathological appearance and aggressive infiltration of $\mathrm{IgG}^{+}$plasma cells into the tissues are the major features of IgG4-RD, whereas the presence of epithelioid cell granulomas and prominent neutrophilic infiltration are relatively inconsistent with the diagnosis of IgG4-RD except for those with a background typical for IgG4-RD [3,9]. These features are suspicious of granulomatosis with polyangiitis.

A

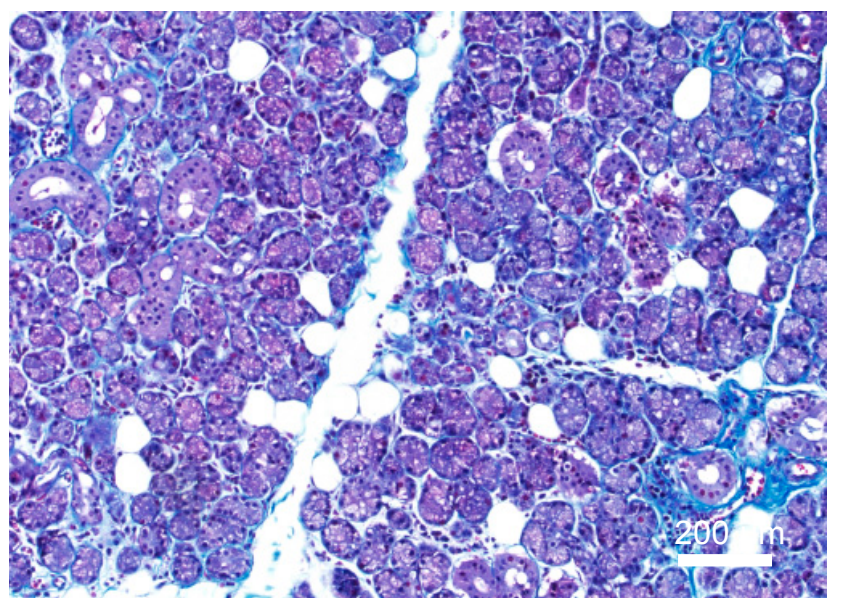

B

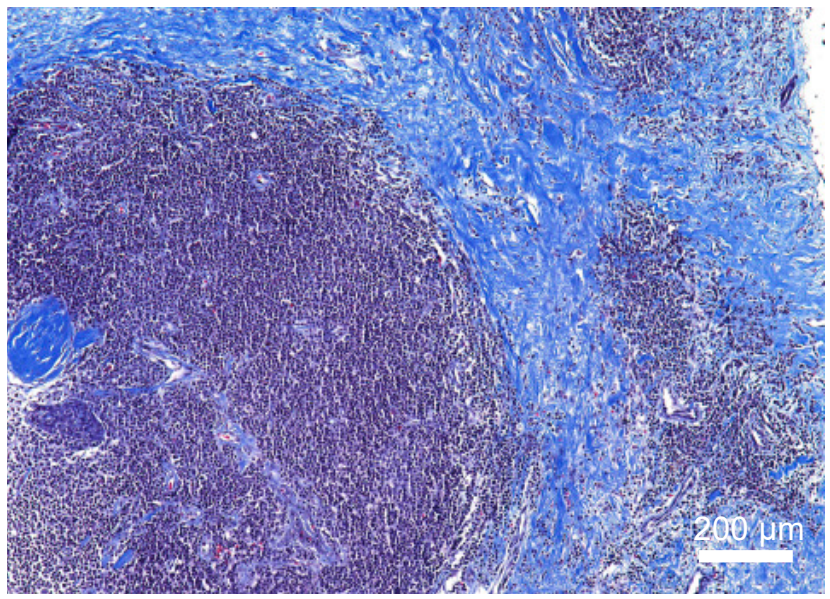

Figure 1. Infiltration of lymphocytes and tissue fibrosis in IgG4-RD. Masson trichrome staining in submandibular glands from a healthy control (A) and a patient with IgG4-RD (B). Massive infiltration of lymphocytes and fibrosis are seen in IgG4-RD, while normal glandular structures are observed in healthy control.

Since IgG4-RD was first described, many studies have attempted to clarify its pathogenesis, and our knowledge of this disease is being updated daily [10-17]. Here, we review the current state of knowledge regarding the underlying immune mechanisms related to IgG4-RD with a focus on fibrosis.

\section{Targeted Therapy Has Proven the Contribution of B Cell Lineages to IgG4-RD}

Most clinical manifestations in patients with IgG4-RD respond to glucocorticoid treatment, which is the current standard of care for IgG4-related disease worldwide [18,19]. Glucocorticoids regulate gene transcription by binding to cytosolic glucocorticoid receptors, and then inhibiting inflammation and regulating immune responses [20]. Several studies including a multicenter phase II prospective clinical trial and a randomized controlled trial have shown the effectiveness of glucocorticoid therapy for IgG4-RD [21,22]. Conventional treatment starts with a prednisolone dose of $0.6-1.0 \mathrm{mg} / \mathrm{kg}$ daily. After $2-4$ weeks, the dose is tapered by $5 \mathrm{mg}$ every 1-2 weeks, based on clinical responses [23]. Glucocorticoid therapy is characterized by rapid responsiveness and clinical improvement after its initiation in patients with IgG4-RD, and a follow-up serological evaluation should be performed approximately 2 weeks after the end of treatment. Exclusion of IgG4-RD from diagnosis should be considered if the patient fails to respond to an adequate course of glucocorticoids following exclusion criteria definitions of the ACR-EULAR IgG4-RD classification [24].

Glucocorticoids are well established as a treatment for patients with IgG4-RD. However, the regimens involve high doses that can induce diabetes and exacerbate existing diabetes and infections, furthermore, glucocorticoids sometimes fail to induce treatment-free remission [25]. Because hypergammaglobulinemia and plasmablast expansion can occur in 
patients with IgG4-RD, anti-CD20 mediated B-cell therapy using rituximab was studied in IgG4-RD patients as an alternative therapy to glucocorticoids [26-28]. B cell killing by rituximab is largely mediated by antibody dependent cell-mediated cytotoxicity; however, complement-mediated lysis and the induction of apoptosis might also contribute to B cell killing depending on the tissue microenvironment [29-33]. B cell depletion therapy by rituximab induced a period of remission and swift clinical improvement in patients with IgG4-RD [28]. The therapy also induced rapid reductions in serum IgG4, the number of plasmablasts and $\mathrm{CD}^{+}$CTLs in the blood and tissues, and tissue fibrosis by attenuating the secretory phenotype of myofibroblasts [26,34,35]. These clinical observations following B-cell depletion therapy consistently suggest the central role of B cells in the pathogenesis of IgG4-RD.

\subsection{Plasmablasts}

Circulating plasmablasts and activated B cells that express high levels of surface IgG4 ${ }^{+}$ and SLAMF7 are expanded in high numbers and undergo somatic hypermutation in IgG4$\mathrm{RD}$, suggesting that these cells can present peptide antigens by MHC class II molecules to $\mathrm{CD}^{+} \mathrm{T}$ cells, which likely contributes to the pathogenesis of IgG4-RD [36] (Figure 2). The subsequent study reported B cells including plasmablasts obtained from patients with IgG4-RD produced pro-fibrotic molecules including platelet-derived growth factor (PDGF)$B$ and lysyl oxidase like (LOXL)-2, which stimulated collagen production by fibroblasts through production of the chemotactic factors CCL4, CCL5, and CCL11 [37]. They also showed that plasmablasts expressed sets of genes implicated in fibroblast activation and proliferation, and concluded that B cells contributed directly to tissue fibrosis in patients with IgG4-RD.

A

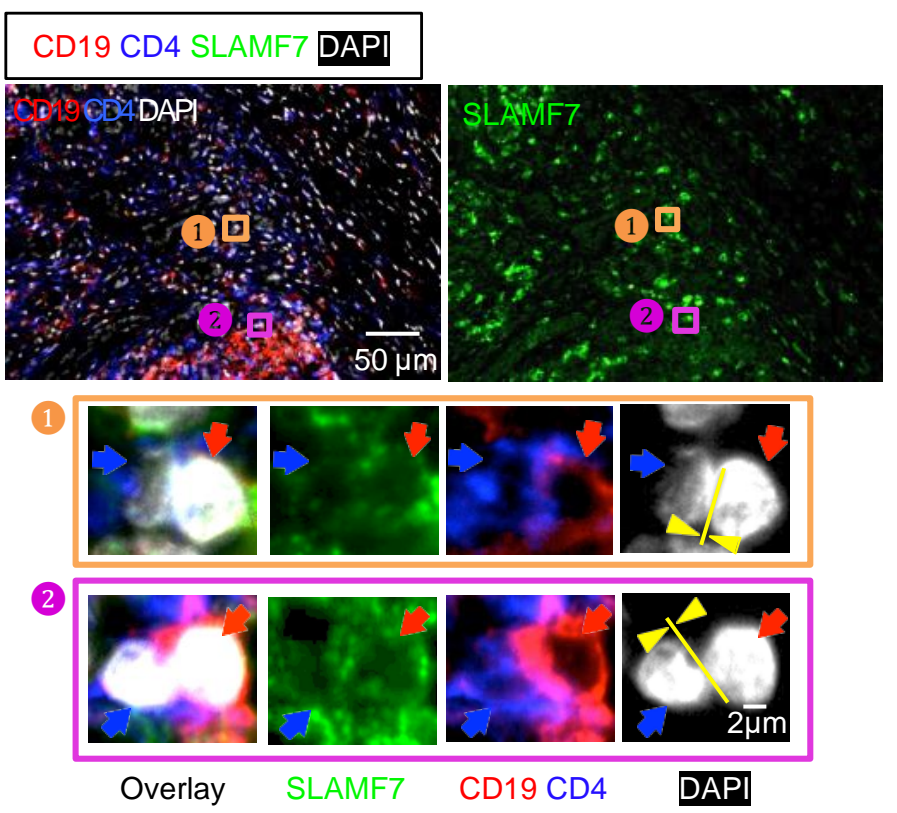

B
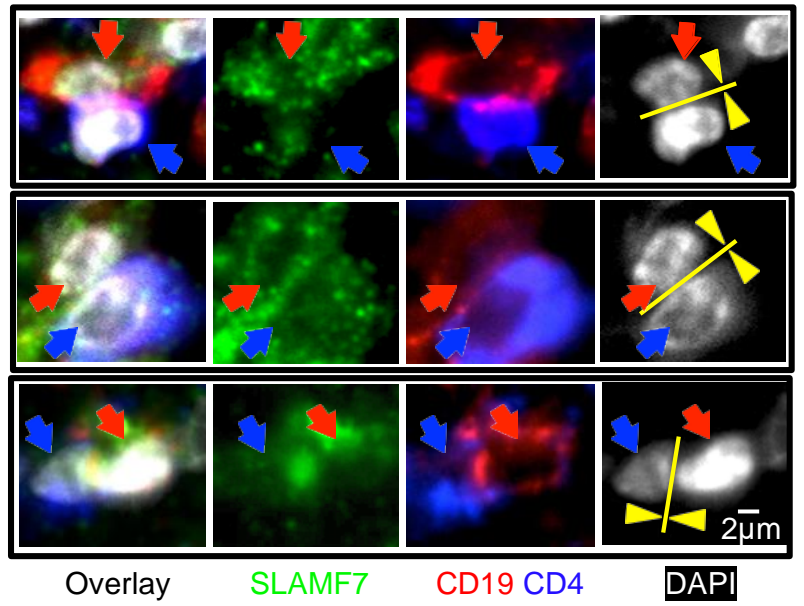

Figure 2. High numbers of CD4 ${ }^{+} \mathrm{CTLs}$ and activated B cells are frequently conjugated in IgG4-RD. (A) Representative multi-color immunofluorescence images of CD19 (red), CD4 (blue), SLAMF7 (green), and DAPI (white) staining in a submandibular gland from a patient with IgG4-RD. Orange and pink rectangles represent SLAMF7 ${ }^{+} \mathrm{CD} 4^{+} \mathrm{CTLs}$ (blue arrows), SLAMF7 ${ }^{+}$activated B (red arrows) cells, and cells that they are in contact with. (B) SLAMF7 ${ }^{+}$CD $4^{+}$CTLs (blue arrows), $\mathrm{SLAMF7}^{+}$activated B (red arrows) cells, and cells they are in contact with, in IgG4-RD tissue lesions. 


\subsection{Other B Cell Subsets}

Regulatory B cells (Breg), which produce IL-10 and TGF- $\beta$ that have immunoregulatory effects, were also reported to be involved in the pathogenesis of IgG4-RD. Sumimoto et al. revealed a significant increase in $\mathrm{CD} 19^{+} \mathrm{CD} 24^{\text {high }} \mathrm{CD} 38^{\text {high }}$ Breg and a relative decrease in $\mathrm{CD} 19^{+} \mathrm{CD} 24^{\text {high }} \mathrm{CD} 27^{+}$Breg in the peripheral blood of type 1 AIP patients, although IL-10 producing B cells were not significantly different from those in type 1 AIP patients and controls [38]. Lin et al. reported the opposite result: IgG4-RD patients had a lower frequency of $\mathrm{CD} 19^{+} \mathrm{CD} 24^{\text {high }} \mathrm{CD} 27^{+}$Breg compared with primary Sjogren syndrome patients and healthy controls [39]. Considering these inconsistent results and uncertainty about the actual role of Breg, further studies are needed to determine their role in the pathogenesis of IgG4-RD.

Another B cell subpopulation, $\mathrm{CD} 27^{+}$memory B cells, may suppress the activity of IgG4-RD. Glucocorticoid therapy-induced disease remission was accompanied by reductions in naïve B cells, plasmablasts, and plasma cells, and an increase in $\mathrm{CD} 27^{+}$memory B cells [40]. Given that memory B cells also express high affinity B cell receptors, resemble antigen-presenting cells (APC), and produce high affinity antibodies, elucidating the role of memory B cells in the pathogenesis of IgG4-RD is important [41,42].

\section{Therapeutic Drugs That Might Change the Treatment of IgG4-RD}

The short-term prognosis of IgG4-RD after immunosuppression therapy with glucocorticoids and rituximab is relatively good but some cases exhibit relapses following treatment [43,44]. In addition, the long-term outcomes of treatment are unknown, although several unknown factors were reported to affect long-term outcomes including the development of fibrosis and associated malignancy $[45,46]$. Therefore, further improvements in treatment are expected.

Other therapeutic drugs that target $B$ cells have been studied in the past few years and some are currently in phase 3 clinical trials $[15,47,48]$. First, a clinical trial of obexelimab (XmAb5871), a monoclonal anti-CD19 antibody with high affinity for Fc $\gamma$ RIIb on B cells, has been completed in the US [49]. A clinical phase 3 trial has been initiated for inebilizumab, a humanized anti-CD19 monoclonal antibody. Yamamoto et al. recently reported the usefulness of belimumab, an anti-B-cell activating factor of the tumor necrosis factor family, for treating IgG4-RD [50]. A clinical trial of elotuzumab, a monoclonal antibody directed against SLAMF7, is also underway. The surface marker SLAMF7 is expressed on B cells and $\mathrm{CD}^{+}$CTLs, and therefore might affect T cells. Molecular-targeted Bruton's tyrosine kinase inhibitors such as zanubrutinib and rilzabrutinib have also been advanced to clinical trials. Current therapeutic targets and novel potential targets are summarized in Figure 3. Further studies focusing on the interactions between B cells and T cells are needed to develop promising therapies for the treatment of IgG4-RD [50]. 


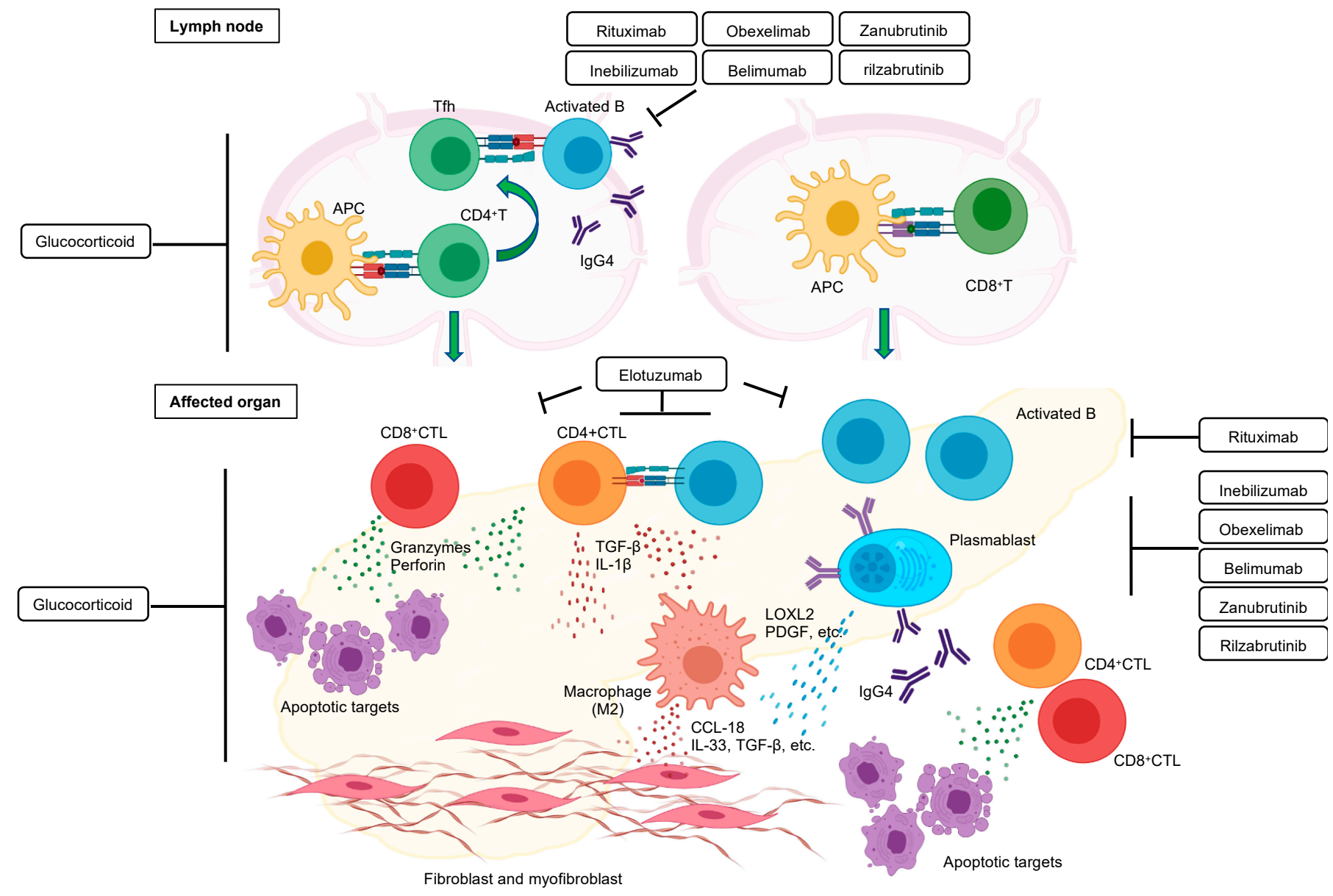

Figure 3. Schematic model of the pathogenesis and fibrosis of IgG4-RD. Self-antigen presented by MHC-class II on antigen presenting cells (APC) activates naïve B cells and CD4 ${ }^{+} \mathrm{T}$ cells in lymph nodes. Some $\mathrm{CD}^{+} \mathrm{T}$ cells differentiate into Tfh cells and collaborate with B cells to drive IgG4 class switching, somatic hypermutation, and plasmablast differentiation of antigen-detecting B cells. Activated B cells and CD4 ${ }^{+} \mathrm{T}$ cells then traffic to the target organ. In the affected organ, activated B cells help previously activated $\mathrm{CD} 4^{+} \mathrm{T}$ cells to differentiate into $\mathrm{CD} 4^{+} \mathrm{CTLs}$, inducing cell apoptosis (possibly mesenchymal cells) with CD8 ${ }^{+}$CTLs, which are activated by self-peptide presented by MHC-class I on APC in lymph nodes. The subsequent remodeling orchestrated by proteins secreted by T cells, B cells, and macrophages leads to fibrosis. Current and potential therapeutic drugs and their target cells are shown. These drugs act primarily on B cells and may inhibit fibrotic processes.

\section{4. $\mathrm{CD}^{+}$T Cells}

B cells are thought to have a critical role in the pathogenesis of IgG4-RD; however, $\mathrm{CD}^{+} \mathrm{T}$ cells are also the main population of infiltrating immune cells in IgG4-RD tissue lesions [51]. Several types of $\mathrm{CD}^{+} \mathrm{T}$ cell subsets were reported to be involved in IgG4-RD pathogenesis, but given the complexity of the immune mechanisms involved, it is unlikely that a single or few subsets are involved in the pathogenesis. Here, we describe and focus on $\mathrm{CD}^{+} \mathrm{T}$ cell subsets that were reported to be associated with the pathogenesis of IgG4-RD.

\subsection{Tfh Cells}

Given the elevation of serum IgG4 levels and presence of clonally expanded classswitched plasmablasts in IgG4-RD, germinal center (GC) reactions should be investigated. $\mathrm{T}$ follicular helper (Tfh) cells, which express high levels of the chemokine receptor CXCR5, are specialized providers of T cell help to B cells, and they promote isotype switching, somatic 
hypermutation, GC formation, and the selection of high-affinity B cells in GCs [52,53]. Tfh cells are related to the class-switching of B cells in a T-cell dependent manner [53].

IL-4 and IL-10 are key cytokines that regulate IgG4 production [54]. Therefore, Tfh cells that produce these cytokines may be involved in the pathogenesis of IgG4-RD. Because of their accessibility, circulating Tfh cells were investigated first in IgG4-RD [55,56]. On the basis of the differential expression pattern of their surface chemokine receptors, circulating Tfh cells can be classified into three subsets: Tfh1, Tfh2, and Tfh 17 cells. Akiyama et al. revealed that circulating Tfh 2 cells were expanded in the blood of IgG4-RD patients, and their levels were associated with levels of circulating plasmablasts, serum IgG4, and IL-4 [56]. The same authors also showed that Tfh 2 cells helped naive $B$ cells differentiate into plasmablasts and produce IgG4 through co-culture experiments [56]. Another group recently reported that IL$4^{+} \mathrm{BATF}^{+} \mathrm{Tfh}$ cells were expanded in lymphoid organs from patients with IgG4-RD, and that this Tfh subset was linked to specific class-switching to IgG4 after contact with activation-induced cytidine deaminase (AID)-expressing B cells in extrafollicular sites [57].

In addition to IL-4, IL-10 secreting T cells may contribute to the pathogenesis of IgG4-RD, and the presence of IL-10 producing Tfh cells in IgG4-RD patients was reported recently [58]. Furthermore, $\mathrm{T}$ follicular regulatory (Tfr) cells, a specialized Tfh cell subset regulated by forkhead box P3 (Foxp3), similar to Treg cells, were reported to be expanded and produce IL-10 in IgG4-RD [59,60]. Taken together, a specific Tfh subset may contribute to the pathogenesis of IgG4-RD but some fundamental mechanisms are still poorly understood. Are circulating Tfh cells and tissue-resident Tfh cells in tissues from the same lineage, and do IL-4 producing Tfh cells also produce IL-10 and other cytokines related to IgG4 class-switching? Further experiments, including single-cell approaches, are urgently needed.

\subsection{Th2 Cells}

Early studies suggested the expression of Th2-related cytokines such as IL-4, IL-5, and IL-13 were upregulated in affected tissues of patients with IgG4-RD; it was concluded that Th2 cells had a critical role in the pathogenesis of IgG4-RD [61,62]. However, because these studies did not identify which cells were the source of cytokines, this hypothesis requires further study although the upregulation of Th2-related cytokines in IgG4-RD has been confirmed by several groups $[63,64]$.

Controversial results were reported by another group. A study of Th2 cells in IgG4-RD demonstrated that their expansion in the circulation was highly correlated with concurrent atopic disease, indicating the importance of identifying diseases that occur concomitantly with allergic diseases [65]. In their follow-up study, they analyzed the $\mathrm{T}$ cell repertoire and revealed Th2 cells were expanded in IgG4-RD patients with atopic disease, although there was no clonal expansion of Th2 cells, which were clonally diverse. This suggests the accumulation of T-cell memory acquired over time against a wide range of environmental allergens [66]. The link between Th2 cells, allergic diseases, and IgG4-RD is still unclear and requires further study.

\section{3. $C D 4^{+}$CTLS}

As noted above, early studies suggested that Th2 cells may have a central role in IgG4-RD, but Pillai et al. caused controversy with a population-level gene expression analysis study. They revealed the dominant gene signatures were $\mathrm{CD} 4^{+} \mathrm{CTLs}$ in total CD4 ${ }^{+}$ effector memory $\mathrm{T}$ cells. This gene signature included the upregulation of genes associated with cytotoxicity, including perforin, granzyme A, granzyme B, and granulysin. CD4 $4^{+}$CTLs were markedly expanded in the blood of patients with IgG4-RD and were highly clonally expanded demonstrated by $\mathrm{T}$ cell receptor $\mathrm{V} \beta$ repertoire assays, whereas Th2 cells were clonally diverse [66]. They also quantitatively analyzed tissue sections from the affected organs of patients with IgG4-RD [67], showing that infiltrating CD4 ${ }^{+} \mathrm{CTLs}$ outnumbered the sparse Th2 cells in all IgG4-RD patients studied. Another group revealed the oligoclonal expansion of $\mathrm{CD}^{+} \mathrm{CTLs}$ in the blood and affected tissues, and indicated that glucocorticoid- 
induced remission in patients with IgG4-RD was associated with a decrease in circulating $\mathrm{CD} 4{ }^{+}$CTLs [68]. These findings suggested that $\mathrm{CD} 4^{+} \mathrm{CTLs}$ might be critically involved in the pathogenesis of IgG4-RD and might be a therapeutic target. Subsequent work by investigators who were the first to report the expansion of $\mathrm{CD} 4^{+} \mathrm{CTL}$ s performed additional phenotyping of $\mathrm{CD} 44^{+} \mathrm{CTLs}$ and revealed that $\mathrm{CD} 27^{\mathrm{lo}} \mathrm{CD} 28^{\mathrm{lo}} \mathrm{CD} 57^{\mathrm{hi}} \mathrm{CD} 4^{+} \mathrm{SLAMF} 7^{+} \mathrm{T}$ cells were the dominant effector subset, and exhibited marked clonal expansion, and differentially expressed genes relevant to cytotoxicity, activation, and enhanced metabolism [69] (Figure 2). This subset correlated with a more severe clinical phenotype of IgG4-RD and, consistent with the effector phenotype in an anti-viral context, had upregulated CX3CR1 and GPR56 and downregulated CD127 in patients with IgG4-RD.

In summary, the remarkable clonal expansion of CD4 $4^{+}$CTLs in patients with IgG4RD suggests that these cells proliferated following antigen presentation by MHC class II molecules. Identifying the antigens that promote $\mathrm{CD} 4^{+} \mathrm{CTL}$ expansion in patients with IgG4-RD and determining whether different epitopes derived from the same antigen are responsible for the expansions of $\mathrm{CD} 4^{+} \mathrm{CTL}$ and $\mathrm{B}$ cells remain critical questions.

\section{4. $\mathrm{CD} 8^{+} \mathrm{T}$ Cells}

In addition to the roles of $\mathrm{CD} 4{ }^{+} \mathrm{CTLs}, \mathrm{CD} 8{ }^{+} \mathrm{CTLs}$ have been implicated in the pathogenesis of IgG4-RD, although only a few reports are available. Cory et al. recently reported that GZMA ${ }^{+} \mathrm{CD} 8^{+} \mathrm{CTLs}$ infiltrated into tissue lesions in numbers that approximated those of infiltrating $\mathrm{CD} 4^{+} \mathrm{CTLs}$, and that most tissue infiltrating $\mathrm{CD} 8{ }^{+} \mathrm{CTLs}$ had an activated phenotype [69]. Furthermore, they reported that the accumulation of circulating CD $8^{+} \mathrm{CTLs}$ with cytotoxic activity in the blood of IgG4-RD patients corresponded with disease severity and circulating effector $\mathrm{CD} 4^{+} \mathrm{CTL}$ expansion. In the same report, the authors proposed an interesting idea about the synergistic effect between $\mathrm{CD} 4^{+} \mathrm{CTLs}$ and $\mathrm{CD} 8^{+} \mathrm{CTLs}$ : naive CD8 ${ }^{+}$ $\mathrm{T}$ cells are activated by the presentation of self-peptides on MHC class I molecules related to the cytotoxic effects of $\mathrm{CD} 4^{+} \mathrm{CTL}$ in the pathogenesis of IgG4-RD. This hypothesis should be verified by functional studies.

\section{What Is the Target of T Cells with a Cytotoxic Phenotype?}

As already mentioned, the abundance of $\mathrm{CD} 4^{+} \mathrm{CTLs}$ has been reported in several autoimmune fibrotic diseases including SSc, fibrosing mediastinitis, rheumatoid arthritis, multiple sclerosis, and IgG4-RD [66,70-74]. In an SSc study by Maehara et al., CD4 ${ }^{+} \mathrm{CTLs}$ were in frequent contact with apoptotic cells expressing MHC class II molecules, and CD4 ${ }^{+} \mathrm{CTL}-$ mediated cell death was suggested as a mechanism leading to tissue remodeling and fibrosis in the context of SSc. Similarly, circulating CD4 ${ }^{+} \mathrm{T}$ cells from IgG4-RD patients acquired a cytotoxic phenotype following TCR activation and the massive accumulation of $\mathrm{CD} 4{ }^{+} \mathrm{CTL}$ and apoptotic cells with HLA-DR expression were observed in tissue lesions, suggesting $\mathrm{CD} 4^{+} \mathrm{CTL}$ mediated cell death is MHC class II-restricted in IgG4-RD [69]. The question then arises as to which type of cell presents self-antigens on MHC class II and are being targeted by CD4 ${ }^{+}$CTLs? Although endothelial cells are a common target of apoptosis in SSc, consistent with the clinical feature of prominent vasculopathy, in IgG4-RD, nonendothelial, nonimmune vimentin ${ }^{+}$mesenchymal cells, rarely of endothelial origin, were the most frequent cell type undergoing apoptosis [69,70]. This frequency was markedly greater than that observed in chronic sialadenitis or salivary glands affected by Sjogren syndrome, a disease linked to increased apoptosis. A potential mechanism of fibrosis in IgG4-RD may involve the antigen-directed MHC class II-restricted killing of target cells by CD4 $4^{+}$CTLs, in addition to fibroblasts that are activated to fill the space left by the cytotoxic process. Additionally, given their relative abundance in the affected tissues, $\mathrm{CD}^{+} \mathrm{CTLs}$ may contribute to apoptotic cell death in lesional tissues in IgG4-RD [69]. Additional studies are required to determine the antigen specificity of clonally expanded $\mathrm{CD} 4^{+} \mathrm{CTLs}$ and $\mathrm{CD} 8{ }^{+} \mathrm{CTLs}$, and whether such antigens are overexpressed by cells undergoing apoptotic cell death. 


\section{M2 Macrophages Participate in the Pathogenesis of IgG4-RD}

A current question in IgG4-RD research is which cells remove the apoptotic cells targeted by cytotoxic cells such as $\mathrm{CD} 4^{+} \mathrm{CTLs}$ and $\mathrm{CD} 8^{+} \mathrm{CTLs}$ ? Macrophages are thought to also contribute to the pathogenesis of IgG4-RD. Macrophages can be broadly classified into two categories: classically activated macrophages (M1) stimulated by Th1 responses and alternatively activated macrophages (M2) stimulated by Th2 responses [75]. M1 macrophages produce proinflammatory cytokines such as IL-6, IL-12, and TNF- $\alpha$, whereas M2 macrophages contribute to angiogenesis, immune suppression, wound healing, and fibrosis [76].

Several quantitative studies of tissues from salivary glands affected by IgG4-RD demonstrated the presence of abundant macrophages that expressed M2 markers [77-82]. A recent study showed infiltrating M2 macrophages frequently interacted with activated T and B cells, and apoptotic cells in the tissue lesions [79]. Given that macrophages secrete pro-fibrotic molecules and are preferentially accumulated within highly fibrotic areas of diseased tissues, M2 macrophages may act as "cleaners and repairers", via interactions with T cells and B cells, by phagocytosing apoptotic cells in IgG4-RD.

Inappropriate signaling by Toll-like receptors (TLRs), a family of transmembrane receptors that have a critical role in the activation of innate immunity and antigen-specific acquired immunity, exacerbates autoimmune diseases [83,84]. Another study showed that TLR7-expressing M2 macrophages secreted IL-33 and fibrotic molecules, leading to IgG4 class-switching and fibrosis in IgG4-RD [78]. The authors of that study established human TLR7-transgenic mice that developed symptoms including organ enlargement and fibrosis, which are characteristic symptoms of IgG4-RD. Further experiments using TLR7-transgenic mice are awaited. Furthermore, the authors examined whether the fibrotic mechanism involved the TLR7 pathway and demonstrated that M2 macrophages promoted fibrosis in IgG4-RD by increasing the production of fibrotic cytokines via TLR7/IL-1 receptorassociated kinase 4 (IRAK4)/NF-kB signaling [85].

\section{The Role of IgG4 in IgG4-RD}

Although elevated serum levels of IgG4 are a clinical characteristic of IgG4-RD, the role of IgG4 itself in the pathogenesis of IgG4-RD is still unclear. Furthermore, the elevation of serum IgG4 levels is not observed in all cases, which has made it difficult to determine its specific role in IgG4-RD [34,86].

IgG4 is an immunoglobulin with two unique properties: Fab-arm exchange, and lowaffinity binding to $\mathrm{C} 1 \mathrm{q}$ and $\mathrm{Fc}$ receptors $[87,88]$. Because of these features, IgG4 is thought to be an anti-inflammatory antibody, which might have a protective role [89]. For example, beekeepers, animal laboratory workers, and individuals undergoing allergen immunotherapy have high serum IgG4 protection against anaphylactic reactions [90,91].

Animal studies have helped elucidate the role of IgG4 in the pathogenesis of IgG4-RD. The subcutaneous injection of purified IgG1 and IgG4 from patients with IgG4-RD into neonatal BALB/c mice induced pancreatic and salivary gland injuries, organs commonly affected by IgG4-RD in humans [92]. The authors also reported that destructive changes in the pancreas were induced by IgG1 rather than by IgG4, and that the potent pathogenic activity of patient IgG1 was significantly inhibited by the simultaneous injection of patient IgG4. The binding of patient IgG1 and IgG4 to pancreatic tissues was confirmed in a mouse model of IgG4-RD and AIP tissue samples, although the antigenic specificity was not established in these studies.

Of note, another recent study showed a synergistic effect of IgG4 and CTLs in the pathogenesis of IgG4-RD [93]. They established mice expressing ovalbumin (OVA) in the pancreatic islets and evaluated the pathogenic function of IgG4 by using recombinant OVA-specific human IgG4 monoclonal antibodies. No inflammatory effect was found after the transfer of IgG4 alone. However, co-transfer of OVA-specific human IgG4 monoclonal antibodies with OVA-specific CTLs induced severe tissue damage with dense lymphocytic inflammation in the pancreas of mice. Subsequently, they have shown that the transfer of 
OVA-specific $\mathrm{CD}^{+}$helper T cells into these mice induced anti-OVA antibody production through the acquisition of a Tfh phenotype mediated by the JAK/STAT signaling pathway.

These seemingly contradictory results suggest IgG4 itself may contribute to some aspects of disease onset or progression of IgG4-RD. Specific autoantibodies with unequivocal pathogenic significance remain to be identified and whether IgG4 produced by patients with IgG4-RD have antigen-specificity to peptides recently reported such as prohibitin, annexin A11, laminin 511-E8, galectin-3, and IL-1 receptor antagonist (IL-1RA) should be further investigated [94-98].

\section{Potential Triggers of IgG4-RD: Autoantigens}

Antigenic triggers that induce an immune response and the clonal expansion of $\mathrm{T}$ and B cells in patients with IgG4-RD have not been identified to date. Recently, antibodies against prohibitin, annexin A11, and laminin 511-E8 have been described as potential autoantigens [94-97]. However, another group reported that antibodies against prohibitin, annexin A11, and laminin 511-E8 were present only in a small proportion of IgG4-RD patients, suggesting ethnic factors might influence the formation of autoantigens.

Perugino et al. used next-generation sequencing to identify the clonal expansion of circulating plasmablasts and the sequencing of $\mathrm{IgH}$ and $\mathrm{L}$ chain genes at the single $\mathrm{B}$ cell level to generate antibodies produced by the most clonally expanded activated B cells in active IgG4-RD patients. As a result, antibodies to galectin-3 were observed in $28 \%$ of patients with IgG4-RD and were rare in healthy controls or patients with idiopathic pulmonary fibrosis. Furthermore, another group confirmed galectin-3 was overexpressed in lesional tissues from IgG4-RD patients using a proteomic approach (liquid chromatography mass spectrometry) [99]. Given that galectin-3 drives processes associated with fibrosis in many fibrotic diseases, it may contribute to tissue fibrosis in IgG4-RD [100].

A recent study by Jarrell et al. identified another autoantibody against human IL-1RA by sequencing clonally expanded plasmablast-derived monoclonal antibody repertoires from a patient with IgG4-RD [98]. They found anti-IL-1RA autoantibodies were associated with a number of affected organs and promoted proinflammatory and pro-fibrotic meditator production in vitro. Therefore, novel immunological mechanisms that promote inflammation and fibrosis in B cell-mediated autoimmune diseases should be further investigated.

\section{Playing Fibrosis in IgG4-RD}

Tissue fibrosis is a representative characteristic of IgG4-RD but an overview of the mechanisms in affected tissues is still unclear. Several types of cells may activate fibroblasts by the secretion of pro-fibrotic molecules, resulting in the production of extracellular matrix proteins that fill the space created by target cell apoptosis.

B cells are an important cell type involved in fibrosis. Activated B cells, plasmablasts, and plasma cells are a feature of many inflammatory diseases, and these cells present antigens to $\mathrm{CD} 4^{+} \mathrm{T}$ cells, secrete cytokines, and may contribute to fibrosis by the secretion of pro-fibrotic molecules. Emanuel et al. recently reported B cells from patients with IgG4-RD produced PDGF-B and LOXL-2, and the direct contributions of B cells to tissue fibrosis in patients with IgG4-RD [37].

T cells are also key participants in IgG4-RD. CD4 ${ }^{+} \mathrm{CTLs}$, the predominant population in IgG4-RD tissue lesions, were reported to directly contribute to fibrosis by activating fibroblasts via the secretion of TGF- $\beta$, IFN- $\gamma$, and IL- $1 \beta[66,67]$. Moreover, CD4 ${ }^{+}$CTLs activate macrophages via TGF- $\beta$, which promotes the clearance of apoptotic cells by efferocytosis, suggesting these cells also contribute indirectly to fibrosis. Although the direct contribution of $\mathrm{CD} 8^{+} \mathrm{T}$ cells has not yet been proven, these cells may promote fibrosis indirectly through their cytotoxic activity and killing target cells by the presentation of peptides on MHC class I molecules [101].

Given the preferential accumulation of M2 macrophages within highly fibrotic areas of affected tissue lesions and strong correlations with the degree of tissue fibrosis, M2 macrophages may have a critical role in remodeling and fibrosis. Fibrosis in IgG4-RD is 
promoted through the secretion of pro-fibrotic molecules such as TGF- $\beta$, IL-33, CCL-18, and IL- 10 by M2 macrophages [77,79]. The role of M2 macrophages as a bridge between adaptive immune cells and fibroblasts in the generation of fibrosis is a promising area for further investigation.

In summary, fibrosis in IgG4-RD is related to numerous pro-fibrotic cytokines secreted by multiple immune cell types, resulting in complex interactions between these cells. The immune response may be triggered by autoantigens after alterations in the environment and the breakdown of self-tolerance. In addition to immune cells, Sasaki et al. reported that IgG4 itself may contribute to fibrosis indirectly in IgG4-RD through synergistic effects with $\mathrm{CD} 4^{+} \mathrm{CTLs}$ and $\mathrm{CD} 8{ }^{+} \mathrm{CTLs}$ [93]. To complete the current fibrosis model in IgG4-RD, investigations of cells in innate immune responses, such as plasmacytoid dendritic cells, basophils, and neutrophils, are also needed.

\section{Orchestration of Immune Cells in the Pathogenesis of IgG4-RD}

An overview model of the pathogenesis of IgG4-RD is presented in Figure 3. The sequential process of immune responses in IgG4-RD is presumably initiated by self-antigens after alterations in the environment and the breakdown of self-tolerance. The presumed self-antigens are presented by APCs by appropriate HLA-class II molecules to naive B and CD4 ${ }^{+} \mathrm{T}$ cells, which are activated. At the same time as activated $\mathrm{CD} 4^{+} \mathrm{T}$ cells and activated $\mathrm{B}$ cells seed target organs, some $\mathrm{CD} 4^{+} \mathrm{T}$ cells differentiate to $\mathrm{Tfh}$ cells, which collaborate with antigendetected B cells to drive IgG4 class switching, somatic hypermutation, and plasmablast differentiation in secondary lymphoid organs. Activated B cells help activated CD4 ${ }^{+} \mathrm{T}$ cells differentiate to $\mathrm{CD} 4^{+} \mathrm{CTLs}$ (multicolor immunofluorescence staining shows frequent $\mathrm{CD} 4^{+} \mathrm{CTL}$ and activated B cell contact; see Figure 2), which then expand clonally, infiltrate tissue sites, and induce the apoptotic cell death of target cells in tissues that express HLA class II molecules. During the pathogenesis of IgG4-RD, apoptosis may also be induced by clonally expanded $\mathrm{CD} 8^{+} \mathrm{CTLs}$, thought to be activated by the presentation of self-peptides (on MHC class I molecules (cross-presentation) expressed by APC in secondary lymphoid organs) discharged from apoptotic cells via the cytotoxic effects of CD4 ${ }^{+} \mathrm{CTLs}$. IgG4 produced from clonally expanded plasmablasts and plasma cells may also cooperate with $\mathrm{CD}^{+} \mathrm{CTLs}$ and $\mathrm{CD} 8^{+} \mathrm{CTLs}$ to induce apoptosis. Macrophages, activated via disease milieu conditions and TGF- $\beta$ secretion from $\mathrm{CD} 4{ }^{+} \mathrm{CTLs}$, engulf apoptotic cells by efferocytosis and produce CCL-18, IL-33, IL-10, and TGF- $\beta$. The secretion of pro-fibrotic molecules including cytokines, chemokines, and enzymes from various types of immune cell-activated fibroblasts and myofibroblasts, results in the production of extracellular matrix proteins. This sequential process, involving many immune cell types organized like an orchestra, clinically manifests as tumor-like masses and organ enlargement, and those sites histopathologically exhibit lymphoplasmacytic infiltrate and storiform fibrosis.

Funding: This work was supported by the Ministry of Education, Culture, Sports, Science, and Technology of Japan (Grant Number: 21KK0163), the Uehara Postdoctoral Fellowship from The Uehara Memorial Foundation, Mochida Memorial Foundation for Medical and Pharmaceutical Research, Asteras Pathology and Metabolism Group and QR program (Wakaba challenge and SENTAN-Q) from Kyushu University to N.K.

Data Availability Statement: The data used in this review are available from the corresponding author upon request.

Acknowledgments: Shiv Pillai, John Stone, Cory Perugino, Hang Liu, Hamid Mattoo, Vinay Mahajan, Emanuel Della-Torre, Lucrezia Rovati, and Hugues Allard-Chamard are thanked for helpful discussions. We thank Shoko Matsui (Health Administration Center, University of Toyama) for their clinical advice. We also thank J. Ludovic Croxford, from Edanz for editing a draft of this manuscript. The schematic model was prepared using Biorender.

Conflicts of Interest: The authors declare no conflict of interest. 


\section{References}

1. Carruthers, M.N.; Stone, J.H.; Khosroshahi, A. The latest on IgG4-RD: A rapidly emerging disease. Curr. Opin. Rheumatol. 2012, 24, 60-69. [CrossRef] [PubMed]

2. Stone, J.H.; Khosroshahi, A.; Deshpande, V.; Chan, J.K.; Heathcote, J.G.; Aalberse, R.; Azumi, A.; Bloch, D.B.; Brugge, W.R.; Carruthers, M.N.; et al. Recommendations for the nomenclature of IgG4-related disease and its individual organ system manifestations. Arthritis Rheumathol. 2012, 64, 3061-3067. [CrossRef] [PubMed]

3. Deshpande, V.; Zen, Y.; Chan, J.K.; Yi, E.E.; Sato, Y.; Yoshino, T.; Klöppel, G.; Heathcote, J.G.; Khosroshahi, A.; Ferry, J.A.; et al. Consensus statement on the pathology of IgG4-related disease. Mod. Pathol. 2012, 25, 1181-1192. [CrossRef]

4. Okazaki, K.; Uchida, K.; Koyabu, M.; Miyoshi, H.; Takaoka, M. Recent advances in the concept and diagnosis of autoimmune pancreatitis and IgG4-related disease. J. Gastroenterol. 2011, 46, 277-288. [CrossRef]

5. Khosroshahi, A.; Stone, J.H. A clinical overview of IgG4-related systemic disease. Curr. Opin. Rheumatol. 2011, 23, 57-66. [CrossRef] [PubMed]

6. Stone, J.H.; Zen, Y.; Deshpande, V. IgG4-related disease. N. Engl. J. Med. 2012, 366, 539-551. [CrossRef] [PubMed]

7. Umehara, H.; Okazaki, K.; Masaki, Y.; Kawano, M.; Yamamoto, M.; Saeki, T.; Matsui, S.; Sumida, T.; Mimori, T.; Tanaka, Y.; et al. A novel clinical entity, IgG4-related disease (IgG4RD): General concept and details. Mod. Rheumatol. 2012, 22, 1-14. [CrossRef]

8. Wallace, Z.S.; Stone, J.H. An update on IgG4-related disease. Curr. Opin. Rheumatol. 2015, 27, 83-90. [CrossRef]

9. Zen, Y.; Nakanuma, Y. IgG4-related disease: A cross-sectional study of 114 cases. Am. J. Surg. Pathol. 2010, 34, 1812-1819. [CrossRef]

10. Perugino, C.A.; Mattoo, H.; Mahajan, V.S.; Maehara, T.; Wallace, Z.S.; Pillai, S.; Stone, J.H. Emerging treatment models in rheumatology: IgG4-related disease: Insights into human immunology and targeted therapies. Arthritis Rheumatol. 2017, 69, 1722-1732. [CrossRef]

11. Maehara, T.; Pillai, S.; Stone, J.H.; Nakamura, S. Clinical features and mechanistic insights regarding IgG4-related dacryoadenitis and sialoadenitis: A review. Int. J. Oral Maxillofac. Surg. 2019, 48, 908-916. [CrossRef] [PubMed]

12. Pillai, S.; Perugino, C.; Kaneko, N. Immune mechanisms of fibrosis and inflammation in IgG4-related disease. Curr. Opin. Rheumatol. 2020, 32, 146-151. [CrossRef] [PubMed]

13. Kamekura, R.; Takahashi, H.; Ichimiya, S. New insights into IgG4-related disease: Emerging new CD4 ${ }^{+}$T-cell subsets. Curr. Opin. Rheumatol. 2019, 31, 9-15. [CrossRef] [PubMed]

14. Perugino, C.A.; Stone, J.H. IgG4-related disease: An update on pathophysiology and implications for clinical care. Nat. Rev. Rheumatol. 2020, 16, 702-714. [CrossRef]

15. Yamamoto, M. B cell targeted therapy for immunoglobulin G4-related disease. Immunol. Med. 2021, 44, 216-222. [CrossRef]

16. Liu, J.; Yin, W.; Westerberg, L.S.; Lee, P.; Gong, Q.; Chen, Y.; Dong, L.; Liu, C. Immune dysregulation in IgG(4)-related disease. Front. Immunol. 2021, 12, 738540. [CrossRef]

17. Hsieh, S.C.; Shen, C.Y.; Liao, H.T.; Chen, M.H.; Wu, C.H.; Li, K.J.; Lu, C.S.; Kuo, Y.M.; Tsai, H.C.; Tsai, C.Y.; et al. The cellular and molecular bases of allergy, inflammation and tissue fibrosis in patients with IgG4-related disease. Int. J. Mol. Sci. 2020, $21,5082$. [CrossRef]

18. Kamisawa, T.; Shimosegawa, T.; Okazaki, K.; Nishino, T.; Watanabe, H.; Kanno, A.; Okumura, F.; Nishikawa, T.; Kobayashi, K.; Ichiya, T.; et al. Standard steroid treatment for autoimmune pancreatitis. Gut 2009, 58, 1504-1507. [CrossRef]

19. Kamisawa, T.; Zen, Y.; Pillai, S.; Stone, J.H. IgG4-related disease. Lancet 2015, 385, 1460-1471. [CrossRef]

20. Cain, D.W.; Cidlowski, J.A. Immune regulation by glucocorticoids. Nat. Rev. Immunol. 2017, 17, 233-247. [CrossRef]

21. Masaki, Y.; Matsui, S.; Saeki, T.; Tsuboi, H.; Hirata, S.; Izumi, Y.; Miyashita, T.; Fujikawa, K.; Dobashi, H.; Susaki, K.; et al. A multicenter phase II prospective clinical trial of glucocorticoid for patients with untreated IgG4-related disease. Mod. Rheumatol. 2017, 27, 849-854. [CrossRef] [PubMed]

22. Masamune, A.; Nishimori, I.; Kikuta, K.; Tsuji, I.; Mizuno, N.; Iiyama, T.; Kanno, A.; Tachibana, Y.; Ito, T.; Kamisawa, T.; et al. Randomised controlled trial of long-term maintenance corticosteroid therapy in patients with autoimmune pancreatitis. Gut 2017, 66, 487-494. [CrossRef] [PubMed]

23. Shimosegawa, T.; Chari, S.T.; Frulloni, L.; Kamisawa, T.; Kawa, S.; Mino-Kenudson, M.; Kim, M.H.; Klöppel, G.; Lerch, M.M.; Löhr, M.; et al. International consensus diagnostic criteria for autoimmune pancreatitis: Guidelines of the International Association of Pancreatology. Pancreas 2011, 40, 352-358. [CrossRef] [PubMed]

24. Wallace, Z.S.; Naden, R.P.; Chari, S.; Choi, H.; Della-Torre, E.; Dicaire, J.F.; Hart, P.A.; Inoue, D.; Kawano, M.; Khosroshahi, A.; et al. The 2019 American College of Rheumatology/European League Against Rheumatism classification criteria for IgG4-related disease. Arthritis Rheumatol. 2020, 72, 7-19. [CrossRef] [PubMed]

25. Khosroshahi, A.; Wallace, Z.S.; Crowe, J.L.; Akamizu, T.; Azumi, A.; Carruthers, M.N.; Chari, S.T.; Della-Torre, E.; Frulloni, L.; Goto, H.; et al. International Consensus Guidance Statement on the management and treatment of IgG4-related disease. Arthritis Rheumatol. 2015, 67, 1688-1699. [CrossRef]

26. Khosroshahi, A.; Bloch, D.B.; Deshpande, V.; Stone, J.H. Rituximab therapy leads to rapid decline of serum IgG4 levels and prompt clinical improvement in IgG4-related systemic disease. Arthritis Rheumathol. 2010, 62, 1755-1762. [CrossRef]

27. Khosroshahi, A.; Carruthers, M.N.; Deshpande, V.; Unizony, S.; Bloch, D.B.; Stone, J.H. Rituximab for the treatment of IgG4-related disease: Lessons from 10 consecutive patients. Medicine 2012, 91, 57-66. [CrossRef] 
28. Carruthers, M.N.; Topazian, M.D.; Khosroshahi, A.; Witzig, T.E.; Wallace, Z.S.; Hart, P.A.; Deshpande, V.; Smyrk, T.C.; Chari, S.; Stone, J.H. Rituximab for IgG4-related disease: A prospective, open-label trial. Ann. Rheum. Dis. 2015, 74, 1171-1177. [CrossRef]

29. Edwards, J.C.; Cambridge, G. B-cell targeting in rheumatoid arthritis and other autoimmune diseases. Nat. Rev. Immunol. 2006, 6, 394-403. [CrossRef]

30. Uchida, J.; Hamaguchi, Y.; Oliver, J.A.; Ravetch, J.V.; Poe, J.C.; Haas, K.M.; Tedder, T.F. The innate mononuclear phagocyte network depletes B lymphocytes through $F_{c}$ receptor-dependent mechanisms during anti-CD20 antibody immunotherapy. J. Exp. Med. 2004, 199, 1659-1669. [CrossRef]

31. Di Gaetano, N.; Cittera, E.; Nota, R.; Vecchi, A.; Grieco, V.; Scanziani, E.; Botto, M.; Introna, M.; Golay, J. Complement activation determines the therapeutic activity of rituximab in vivo. J. Immunol. 2003, 171, 1581-1587. [CrossRef] [PubMed]

32. Teeling, J.L.; French, R.R.; Cragg, M.S.; van den Brakel, J.; Pluyter, M.; Huang, H.; Chan, C.; Parren, P.W.; Hack, C.E.; Dechant, M.; et al. Characterization of new human CD20 monoclonal antibodies with potent cytolytic activity against nonHodgkin lymphomas. Blood 2004, 104, 1793-1800. [CrossRef] [PubMed]

33. Gong, Q.; Ou, Q.; Ye, S.; Lee, W.P.; Cornelius, J.; Diehl, L.; Lin, W.Y.; Hu, Z.; Lu, Y.; Chen, Y.; et al. Importance of cellular microenvironment and circulatory dynamics in B cell immunotherapy. J. Immunol. 2005, 174, 817-826. [CrossRef] [PubMed]

34. Wallace, Z.S.; Mattoo, H.; Carruthers, M.; Mahajan, V.S.; Della Torre, E.; Lee, H.; Kulikova, M.; Deshpande, V.; Pillai, S.; Stone, J.H. Plasmablasts as a biomarker for IgG4-related disease, independent of serum IgG4 concentrations. Ann. Rheum. Dis. 2015, 74, 190-195. [CrossRef]

35. Della-Torre, E.; Feeney, E.; Deshpande, V.; Mattoo, H.; Mahajan, V.; Kulikova, M.; Wallace, Z.S.; Carruthers, M.; Chung, R.T.; Pillai, S.; et al. B-cell depletion attenuates serological biomarkers of fibrosis and myofibroblast activation in IgG4-related disease. Ann. Rheum. Dis. 2015, 74, 2236-2243. [CrossRef] [PubMed]

36. Mattoo, H.; Mahajan, V.S.; Della-Torre, E.; Sekigami, Y.; Carruthers, M.; Wallace, Z.S.; Deshpande, V.; Stone, J.H.; Pillai, S. De novo oligoclonal expansions of circulating plasmablasts in active and relapsing IgG4-related disease. J. Allergy Clin. Immunol. 2014, 134, 679-687. [CrossRef]

37. Della-Torre, E.; Rigamonti, E.; Perugino, C.; Baghai-Sain, S.; Sun, N.; Kaneko, N.; Maehara, T.; Rovati, L.; Ponzoni, M.; Milani, R.; et al. B lymphocytes directly contribute to tissue fibrosis in patients with IgG(4)-related disease. J. Allergy Clin. Immunol. 2020, 145, 968-981.e14. [CrossRef]

38. Sumimoto, K.; Uchida, K.; Kusuda, T.; Mitsuyama, T.; Sakaguchi, Y.; Fukui, T.; Matsushita, M.; Takaoka, M.; Nishio, A.; Okazaki, K. The role of CD19+ CD24high CD38high and CD19+ CD24high CD27+ regulatory B cells in patients with type 1 autoimmune pancreatitis. Pancreatology 2014, 14, 193-200. [CrossRef]

39. Lin, W.; Jin, L.; Chen, H.; Wu, Q.; Fei, Y.; Zheng, W.; Wang, Q.; Li, P.; Li, Y.; Zhang, W.; et al. B cell subsets and dysfunction of regulatory B cells in IgG4-related diseases and primary Sjögren's syndrome: The similarities and differences. Arthritis Res. Ther. 2014, 16, R118. [CrossRef]

40. Lanzillotta, M.; Della-Torre, E.; Milani, R.; Bozzolo, E.; Bozzalla-Cassione, E.; Rovati, L.; Arcidiacono, P.G.; Partelli, S.; Falconi, M.; Ciceri, F.; et al. Effects of glucocorticoids on B-cell subpopulations in patients with IgG4-related disease. Clin. Exp. Rheumatol. 2019, 37 (Suppl. S118), 159-166.

41. Nowosad, C.R.; Spillane, K.M.; Tolar, P. Germinal center B cells recognize antigen through a specialized immune synapse architecture. Nat. Immunol. 2016, 17, 870-877. [CrossRef] [PubMed]

42. Sacquin, A.; Gador, M.; Fazilleau, N. The strength of BCR signaling shapes terminal development of follicular helper T cells in mice. Eur. J. Immunol. 2017, 47, 1295-1304. [CrossRef] [PubMed]

43. Yamamoto, M.; Takahashi, H.; Ishigami, K.; Yajima, H.; Shimizu, Y.; Tabeya, T.; Matsui, M.; Suzuki, C.; Naishiro, Y.; Imai, K.; et al. Relapse patterns in IgG4-related disease. Ann. Rheum. Dis. 2012, 71, 1755. [CrossRef] [PubMed]

44. Wallace, Z.S.; Mattoo, H.; Mahajan, V.S.; Kulikova, M.; Lu, L.; Deshpande, V.; Choi, H.K.; Pillai, S.; Stone, J.H. Predictors of disease relapse in IgG4-related disease following rituximab. Rheumatology 2016, 55, 1000-1008. [CrossRef] [PubMed]

45. Hart, P.A.; Kamisawa, T.; Brugge, W.R.; Chung, J.B.; Culver, E.L.; Czakó, L.; Frulloni, L.; Go, V.L.; Gress, T.M.; Kim, M.H.; et al. Long-term outcomes of autoimmune pancreatitis: A multicentre, international analysis. Gut 2013, 62, 1771-1776. [CrossRef]

46. Kamisawa, T.; Ohara, H.; Kim, M.H.; Kanno, A.; Okazaki, K.; Fujita, N. Role of endoscopy in the diagnosis of autoimmune pancreatitis and immunoglobulin G4-related sclerosing cholangitis. Dig. Endosc. 2014, 26, 627-635. [CrossRef]

47. Zhao, Q. Bispecific antibodies for autoimmune and inflammatory diseases: Clinical progress to date. BioDrugs 2020, 34, 111-119. [CrossRef]

48. Lanzillotta, M.; Mancuso, G.; Della-Torre, E. Advances in the diagnosis and management of IgG4 related disease. BMJ 2020, 369 , m1067. [CrossRef]

49. Szili, D.; Cserhalmi, M.; Bankó, Z.; Nagy, G.; Szymkowski, D.E.; Sármay, G. Suppression of innate and adaptive B cell activation pathways by antibody coengagement of Fc $\gamma$ RIIb and CD19. mAbs 2014, 6, 991-999. [CrossRef]

50. Yamamoto, M.; Aochi, S.; Suzuki, C.; Nakamura, S.; Murakami, R.; Ogawa, Y.; Takahashi, H. A case with good response to belimumab for lupus nephritis complicated by IgG4-related disease. Lupus 2019, 28, 786-789. [CrossRef]

51. Mahajan, V.S.; Mattoo, H.; Deshpande, V.; Pillai, S.S.; Stone, J.H. IgG4-related disease. Annu. Rev. Pathol. 2014, 9, 315-347. [CrossRef] [PubMed]

52. King, C.; Tangye, S.G.; Mackay, C.R. T follicular helper (TFH) cells in normal and dysregulated immune responses. Annu. Rev. Immunol. 2008, 26, 741-766. [CrossRef] [PubMed] 
53. Crotty, S. T follicular helper cell differentiation, function, and roles in disease. Immunity 2014, 41, 529-542. [CrossRef] [PubMed]

54. Jeannin, P.; Lecoanet, S.; Delneste, Y.; Gauchat, J.F.; Bonnefoy, J.Y. IgE versus IgG4 production can be differentially regulated by IL-10. J. Immunol. 1998, 160, 3555-3561. [PubMed]

55. Morita, R.; Schmitt, N.; Bentebibel, S.E.; Ranganathan, R.; Bourdery, L.; Zurawski, G.; Foucat, E.; Dullaers, M.; Oh, S.; Sabzghabaei, N.; et al. Human blood CXCR5(+)CD4(+) T cells are counterparts of T follicular cells and contain specific subsets that differentially support antibody secretion. Immunity 2011, 34, 108-121. [CrossRef]

56. Akiyama, M.; Suzuki, K.; Yamaoka, K.; Yasuoka, H.; Takeshita, M.; Kaneko, Y.; Kondo, H.; Kassai, Y.; Miyazaki, T.; Morita, R.; et al. Number of circulating follicular helper $2 \mathrm{~T}$ cells correlates with IgG4 and interleukin-4 levels and plasmablast numbers in IgG4-related disease. Arthritis Rheumatol. 2015, 67, 2476-2481. [CrossRef]

57. Maehara, T.; Mattoo, H.; Mahajan, V.S.; Murphy, S.J.; Yuen, G.J.; Ishiguro, N.; Ohta, M.; Moriyama, M.; Saeki, T.; Yamamoto, H.; et al. The expansion in lymphoid organs of IL-4(+) BATF(+) T follicular helper cells is linked to IgG4 class switching in vivo. Life Sci. Alliance 2018, 1, e201800050. [CrossRef]

58. Higashioka, K.; Ota, Y.; Maehara, T.; Moriyama, M.; Ayano, M.; Mitoma, H.; Akahoshi, M.; Arinobu, Y.; Horiuchi, T.; Nakamura, S.; et al. Association of circulating SLAMF7+Tfh1 cells with IgG4 levels in patients with IgG4-related disease. BMC Immunol. 2020, 21, 31. [CrossRef]

59. Sage, P.T.; Sharpe, A.H. T follicular regulatory cells in the regulation of B cell responses. Trends Immunol. 2015, 36, 410-418. [CrossRef]

60. Ito, F.; Kamekura, R.; Yamamoto, M.; Takano, K.; Takaki, H.; Yabe, H.; Ikegami, I.; Shigehara, K.; Himi, T.; Takahashi, H.; et al. IL-10(+) T follicular regulatory cells are associated with the pathogenesis of IgG4-related disease. Immunol. Lett. 2019, $207,56-63$. [CrossRef]

61. Zen, Y.; Fujii, T.; Harada, K.; Kawano, M.; Yamada, K.; Takahira, M.; Nakanuma, Y. Th2 and regulatory immune reactions are increased in immunoglobin G4-related sclerosing pancreatitis and cholangitis. Hepatology 2007, 45, 1538-1546. [CrossRef] [PubMed]

62. Tanaka, A.; Moriyama, M.; Nakashima, H.; Miyake, K.; Hayashida, J.N.; Maehara, T.; Shinozaki, S.; Kubo, Y.; Nakamura, S Th2 and regulatory immune reactions contribute to IgG4 production and the initiation of Mikulicz disease. Arthritis Rheumatol. 2012, 64, 254-263. [CrossRef] [PubMed]

63. Müller, T.; Beutler, C.; Picó, A.H.; Otten, M.; Dürr, A.; Al-Abadi, H.; Guckelberger, O.; Meyer zum Büschenfelde, D.; Jöhrens, K.; Volkmann, M.; et al. Increased T-helper 2 cytokines in bile from patients with IgG4-related cholangitis disrupt the tight junctionassociated biliary epithelial cell barrier. Gastroenterology 2013, 144, 1116-1128. [CrossRef] [PubMed]

64. Heeringa, J.J.; Karim, A.F.; van Laar, J.A.M.; Verdijk, R.M.; Paridaens, D.; van Hagen, P.M.; van Zelm, M.C. Expansion of blood $\operatorname{IgG}(4)(+) \mathrm{B}, \mathrm{T}(\mathrm{H}) 2$, and regulatory T cells in patients with $\mathrm{IgG}(4)$-related disease. J. Allergy Clin. Immunol. 2018, 141, 1831-1843.e10. [CrossRef] [PubMed]

65. Mattoo, H.; Della-Torre, E.; Mahajan, V.S.; Stone, J.H.; Pillai, S. Circulating Th2 memory cells in IgG4-related disease are restricted to a defined subset of subjects with atopy. Allergy 2014, 69, 399-402. [CrossRef]

66. Mattoo, H.; Mahajan, V.S.; Maehara, T.; Deshpande, V.; Della-Torre, E.; Wallace, Z.S.; Kulikova, M.; Drijvers, J.M.; Daccache, J.; Carruthers, M.N.; et al. Clonal expansion of CD4(+) cytotoxic T lymphocytes in patients with IgG4-related disease. J. Allergy Clin. Immunol. 2016, 138, 825-838. [CrossRef]

67. Maehara, T.; Mattoo, H.; Ohta, M.; Mahajan, V.S.; Moriyama, M.; Yamauchi, M.; Drijvers, J.; Nakamura, S.; Stone, J.H.; Pillai, S.S Lesional CD4+ IFN-gamma+ cytotoxic T lymphocytes in IgG4-related dacryoadenitis and sialoadenitis. Ann. Rheum. Dis. 2017, 76, 377-385. [CrossRef]

68. Della-Torre, E.; Bozzalla-Cassione, E.; Sciorati, C.; Ruggiero, E.; Lanzillotta, M.; Bonfiglio, S.; Mattoo, H.; Perugino, C.A.; Bozzolo, E.; Rovati, L.; et al. A CD8 $\alpha$-Subset of CD4+SLAMF7+ Cytotoxic T cells is expanded in patients with IgG4-related disease and decreases following glucocorticoid treatment. Arthritis Rheumatol. 2018, 70, 1133-1143. [CrossRef]

69. Perugino, C.A.; Kaneko, N.; Maehara, T.; Mattoo, H.; Kers, J.; Allard-Chamard, H.; Mahajan, V.S.; Liu, H.; Della-Torre, E.; Murphy, S.J.H.; et al. CD4+ and CD8+ cytotoxic T lymphocytes may induce mesenchymal cell apoptosis in IgG4-related disease. J. Allergy Clin. Immunol. 2021, 147, 368-382. [CrossRef]

70. Maehara, T.; Kaneko, N.; Perugino, C.A.; Mattoo, H.; Kers, J.; Allard-Chamard, H.; Mahajan, V.S.; Liu, H.; Murphy, S.J.; Ghebremichael, M.; et al. Cytotoxic CD4+ T lymphocytes may induce endothelial cell apoptosis in systemic sclerosis. J. Clin. Investig. 2020, 130, 2451-2464. [CrossRef]

71. Allard-Chamard, H.; Alsufyani, F.; Kaneko, N.; Xing, K.; Perugino, C.; Mahajan, V.S.; Wheat, J.L.; Deepe, G.S., Jr.; Loyd, J.; Pillai, S. CD4(+)CTLs in fibrosing mediastinitis linked to histoplasma capsulatum. J. Immunol. 2021, 206, 524-530. [CrossRef] [PubMed]

72. Skapenko, A.; Leipe, J.; Lipsky, P.E.; Schulze-Koops, H. The role of the T cell in autoimmune inflammation. Arthritis Res. Ther. 2005, 7 (Suppl. S2), S4-S14. [CrossRef] [PubMed]

73. Sospedra, M.; Martin, R. Immunology of multiple sclerosis. Annu. Rev. Immunol. 2005, 23, 683-747. [CrossRef] [PubMed]

74. Hellings, N.; Raus, J.; Stinissen, P. Insights into the immunopathogenesis of multiple sclerosis. Immunol. Res. 2002, 25, 27-51. [CrossRef]

75. Martinez, F.O.; Sica, A.; Mantovani, A.; Locati, M. Macrophage activation and polarization. Front. Biosci. 2008, $13,453-461$. [CrossRef] 
76. Hong, X.; Min, S.N.; Zhang, Y.Y.; Lin, Y.T.; Wang, F.; Huang, Y.; Yu, G.Y.; Wu, L.L.; Yang, H.Y. TNF- $\alpha$ suppresses autophagic flux in acinar cells in IgG4-related sialadenitis. J. Dent. Res. 2019, 98, 1386-1396. [CrossRef]

77. Furukawa, S.; Moriyama, M.; Miyake, K.; Nakashima, H.; Tanaka, A.; Maehara, T.; Iizuka-Koga, M.; Tsuboi, H.; Hayashida, J.N.; Ishiguro, N.; et al. Interleukin-33 produced by M2 macrophages and other immune cells contributes to Th2 immune reaction of IgG4-related disease. Sci. Rep. 2017, 7, 42413. [CrossRef]

78. Ishiguro, N.; Moriyama, M.; Furusho, K.; Furukawa, S.; Shibata, T.; Murakami, Y.; Chinju, A.; Haque, A.; Gion, Y.; Ohta, M.; et al. Activated M2 macrophages contribute to the pathogenesis of IgG4-related disease via toll-like receptor 7/interleukin-33 signaling. Arthritis Rheumatol. 2020, 72, 166-178. [CrossRef]

79. Rovati, L.; Kaneko, N.; Pedica, F.; Monno, A.; Maehara, T.; Perugino, C.; Lanzillotta, M.; Pecetta, S.; Stone, J.H.; Doglioni, C.; et al. Mer tyrosine kinase (MerTK) as a possible link between resolution of inflammation and tissue fibrosis in IgG4-related disease. Rheumatology 2021, 60, 4929-4941. [CrossRef]

80. Ohta, M.; Moriyama, M.; Maehara, T.; Gion, Y.; Furukawa, S.; Tanaka, A.; Hayashida, J.N.; Yamauchi, M.; Ishiguro, N.; Mikami, Y.; et al. DNA microarray analysis of submandibular glands in IgG4-related disease indicates a role for MARCO and other innate immune-related proteins. Medicine 2016, 95, e2853. [CrossRef]

81. Kawakami, T.; Mizushima, I.; Yamada, K.; Fujii, H.; Ito, K.; Yasuno, T.; Izui, S.; Yamagishi, M.; Huard, B.; Kawano, M. Abundant a proliferation-inducing ligand (APRIL)-producing macrophages contribute to plasma cell accumulation in immunoglobulin G4-related disease. Nephrol. Dial. Transplant. 2019, 34, 960-969. [CrossRef] [PubMed]

82. Furukawa, S.; Moriyama, M.; Tanaka, A.; Maehara, T.; Tsuboi, H.; Iizuka, M.; Hayashida, J.N.; Ohta, M.; Saeki, T.; Notohara, K.; et al. Preferential M2 macrophages contribute to fibrosis in IgG4-related dacryoadenitis and sialoadenitis, so-called Mikulicz's disease. Clin. Immunol. 2015, 156, 9-18. [CrossRef] [PubMed]

83. Hwang, I.Y.; Park, C.; Harrison, K.; Kehrl, J.H. TLR4 signaling augments B lymphocyte migration and overcomes the restriction that limits access to germinal center dark zones. J. Exp. Med. 2009, 206, 2641-2657. [CrossRef] [PubMed]

84. Watanabe, T.; Yamashita, K.; Fujikawa, S.; Sakurai, T.; Kudo, M.; Shiokawa, M.; Kodama, Y.; Uchida, K.; Okazaki, K.; Chiba, T. Involvement of activation of toll-like receptors and nucleotide-binding oligomerization domain-like receptors in enhanced IgG4 responses in autoimmune pancreatitis. Arthritis Rheumatol. 2012, 64, 914-924. [CrossRef]

85. Chinju, A.; Moriyama, M.; Kakizoe-Ishiguro, N.; Chen, H.; Miyahara, Y.; Rafiul Haque, A.S.M.; Furusho, K.; Sakamoto, M.; Kai, K.; Kibe, K.; et al. CD163+ M2 macrophages promote fibrosis in IgG4-related disease via TLR7/IRAK4/NF-kB signaling. Arthritis Rheumatol. 2021. [CrossRef]

86. Wallace, Z.S.; Deshpande, V.; Mattoo, H.; Mahajan, V.S.; Kulikova, M.; Pillai, S.; Stone, J.H. IgG4-related disease: Clinical and laboratory features in one hundred twenty-five patients. Arthritis Rheumatol. 2015, 67, 2466-2475. [CrossRef]

87. Van der Neut Kolfschoten, M.; Schuurman, J.; Losen, M.; Bleeker, W.K.; Martínez-Martínez, P.; Vermeulen, E.; den Bleker, T.H.; Wiegman, L.; Vink, T.; Aarden, L.A.; et al. Anti-inflammatory activity of human IgG4 antibodies by dynamic Fab arm exchange. Science 2007, 317, 1554-1557. [CrossRef]

88. Vergoossen, D.L.E.; Plomp, J.J.; Gstöttner, C.; Fillié-Grijpma, Y.E.; Augustinus, R.; Verpalen, R.; Wuhrer, M.; Parren, P.; Dominguez-Vega, E.; van der Maarel, S.M.; et al. Functional monovalency amplifies the pathogenicity of anti-MuSK IgG4 in myasthenia gravis. Proc. Natl. Acad. Sci. USA 2021, 118, e2020635118. [CrossRef]

89. Aalberse, R.C.; Stapel, S.O.; Schuurman, J.; Rispens, T. Immunoglobulin G4: An odd antibody. Clin. Exp. Allergy 2009, 39, 469-477. [CrossRef]

90. Trampert, D.C.; Hubers, L.M.; van de Graaf, S.F.J.; Beuers, U. On the role of IgG4 in inflammatory conditions: Lessons for IgG4-related disease. Biochim. Biophys. Acta Mol. Basis Dis. 2018, 1864, 1401-1409. [CrossRef]

91. Aalberse, R.C.; van der Gaag, R.; van Leeuwen, J. Serologic aspects of IgG4 antibodies. I. Prolonged immunization results in an IgG4-restricted response. J. Immunol. 1983, 130, 722-726.

92. Shiokawa, M.; Kodama, Y.; Kuriyama, K.; Yoshimura, K.; Tomono, T.; Morita, T.; Kakiuchi, N.; Matsumori, T.; Mima, A.; Nishikawa, Y.; et al. Pathogenicity of IgG in patients with IgG4-related disease. Gut 2016, 65, 1322-1332. [CrossRef] [PubMed]

93. Sasaki, T.; Yajima, T.; Shimaoka, T.; Ogawa, S.; Saito, T.; Yamaoka, K.; Takeuchi, T.; Kubo, M. Synergistic effect of IgG4 antibody and CTLs causes tissue inflammation in IgG4-related disease. Int. Immunol. 2019, 32, 163-174. [CrossRef] [PubMed]

94. Du, H.; Shi, L.; Chen, P.; Yang, W.; Xun, Y.; Yang, C.; Zhao, L.; Zhou, Y.; Chen, G. Prohibitin is involved in patients with IgG4 related disease. PLoS ONE 2015, 10, e0125331. [CrossRef]

95. Hubers, L.M.; Vos, H.; Schuurman, A.R.; Erken, R.; Oude Elferink, R.P.; Burgering, B.; van de Graaf, S.F.J.; Beuers, U. Annexin A11 is targeted by IgG4 and IgG1 autoantibodies in IgG4-related disease. Gut 2018, 67, 728-735. [CrossRef]

96. Shiokawa, M.; Kodama, Y.; Sekiguchi, K.; Kuwada, T.; Tomono, T.; Kuriyama, K.; Yamazaki, H.; Morita, T.; Marui, S.; Sogabe, Y.; et al. Laminin 511 is a target antigen in autoimmune pancreatitis. Sci. Transl. Med. 2018, 10, eaaq0997. [CrossRef]

97. Perugino, C.A.; AlSalem, S.B.; Mattoo, H.; Della-Torre, E.; Mahajan, V.; Ganesh, G.; Allard-Chamard, H.; Wallace, Z.; Montesi, S.B.; Kreuzer, J.; et al. Identification of galectin-3 as an autoantigen in patients with IgG(4)-related disease. J. Allergy Clin. Immunol. 2019, 143, 736-745.e6. [CrossRef]

98. Jarrell, J.A.; Baker, M.C.; Perugino, C.A.; Liu, H.; Bloom, M.S.; Maehara, T.; Wong, H.H.; Lanz, T.V.; Adamska, J.Z.; Kongpachith, S.; et al. Neutralizing anti-IL-1 receptor antagonist autoantibodies induce inflammatory and fibrotic mediators in IgG4-related disease. J. Allergy Clin. Immunol. 2022, 149, 358-368. [CrossRef] 
99. Salah, A.; Yoshifuji, H.; Ito, S.; Kitagori, K.; Kiso, K.; Yamada, N.; Nakajima, T.; Haga, H.; Tsuruyama, T.; Miyagawa-Hayashino, A. High expression of galectin-3 in patients with IgG4-related disease: A proteomic approach. Pathol. Res. Int. 2017, $2017,9312142$. [CrossRef]

100. Li, L.C.; Li, J.; Gao, J. Functions of galectin-3 and its role in fibrotic diseases. J. Pharmacol. Exp. Ther. 2014, 351, 336-343. [CrossRef]

101. Zhang, M.; Zhang, S. T cells in fibrosis and fibrotic diseases. Front. Immunol. 2020, 11, 1142. [CrossRef] [PubMed] 